BENTHM OPEN
CrossMark
Content list available at: www.benthamopen.com/TOBIOMJ/
DOI: $10.2174 / 1875318301808010024,2018,8,24-33$

REVIEW ARTICLE

\title{
Urinary Biomarkers of Oxidative Stress in Atrial Fibrillation
}

Lei Meng ${ }^{\ddagger 1}$, Ricko Wong ${ }^{\ddagger 2}$, Man Yin Tsui ${ }^{3}$, Gary Tse ${ }^{4,5}$, Guangping Li ${ }^{1}$, Tong Liu ${ }^{*}{ }^{1}$ and Gregory Y. H. Lip ${ }^{6}$

${ }^{I}$ Tianjin Key Laboratory of Ionic-Molecular Function of Cardiovascular Disease, Department of Cardiology, Tianjin Institute of Cardiology, Second Hospital of Tianjin Medical University, Tianjin300211, P.R. China

${ }^{2}$ Faculty of Medicine, The University of Notre Dame, Perth, Australia

${ }^{3}$ Li Ka Shing Faculty of Medicine, University of Hong Kong, Hong Kong, SAR, P.R. China

${ }^{4}$ Department of Medicine and Therapeutics, Chinese University of Hong Kong, Hong Kong, SAR, P.R. China

${ }^{5}$ Li Ka Shing Institute of Health Sciences, 30-32 Ngan Shing St, Chinese University of Hong Kong, Hong Kong, SAR, P.R. China

${ }^{6}$ University of Birmingham Institute of Cardiovascular Sciences, City Hospital, BirminghamB18 7QH, United Kingdom

Received: August 13, 2018

Revised: October 8, 2018

Accepted: November 12, 2018

Abstract: There is increasing evidence from molecular studies to support the role of inflammation and increased oxidative stress that produce structural and electrical atrial remodeling to produce Atrial Fbrillation (AF). Oxidative damage to cardiomyocytes yields chemical substances that are secreted in urine. These substances can serve as biomarkers that can be measured, potentially allowing clinicians to quantify oxidative damage to the heart.

Keywords: Atrial fibrillation, Oxidative stress, Urinary biomarkers, Inflammation, CRP, IL-6, Isoprostanes, 8-OHdG, Antioxidant, NADPH oxidase.

\section{INTRODUCTION}

Atrial Fibrillation (AF) is a global epidemic, being the commonest cardiac arrhythmia observed in clinical practice affecting $\approx 5.2$ million people in United States, 10 million people in China and 33 million people worldwide [1 - 4]. With an aging population, AF predisposes affected patients to a higher risk of stroke, heart failure and death, and a lower quality of life [5 - 7]. Furthermore, AF is also the most common serious cardiac arrhythmia in the surgical setting. The incidence of Postoperative Atrial Fbrillation (POAF) in patients with cardiac surgery is around 20 to $40 \%[8,9]$. Several risk factors of AF have been identified, including obesity, hypertension, diabetes and obstructive sleep apnea $[10,11]$. Recently, inflammation and oxidative stress have been implicated in the pathogenesis of AF and its complications [12 - 18]. Accordingly, an imbalance between increased oxidative stress and decreased antioxidant capacity can be due to up-regulation of enzymes such as NADPH oxidase (NOX) and Myeloperoxidase (MPO), leading to the increased production of Reactive Oxygen Species (ROS) [19,20]. The objective of this review article is to provide an overview of the relationships between oxidative stress, inflammation and AF, with a particular focus on quantifying urinary biomarkers to monitor occurrence and progression of AF.

\section{PHYSIOLOGICAL RESPONSE TO OXIDATIVE STRESS}

Cells undergo apoptosis or necrosis when they are under stress. Necrotic cells lose their cell integrity and leak their

\footnotetext{
"Address correspondence to this author at the Tianjin Key Laboratory of Ionic-Molecular Function of Cardiovascular disease, Department of Cardiology, Tianjin Institute of Cardiology, Second Hospital of Tianjin Medical University, Tianjin 300211, People's Republic of China, Tel: +86-22-88328368; Fax: +86-22-28261158. E-mail: liutongdoc@126.com

'The first two authors contribute equally to this work.
} 
intracellular materials [21]. These materials serve as "danger signals" and human body respond to these substances by initiating inflammatory cascades, which involve cytokines such as interleukin (IL)-1, IL-6 and tumour necrosis factor alpha (TNF-alpha). Apoptotic cells are processed by Antigen Presenting Cells (APCs) such as macrophages, releasing cytokines to recruit other immune cells to resolve damage [22]. There are two different types of macrophages: M1 and M2 with distinct functions. M1 macrophages are recruited during the early stage of cell damage with a role to clear dead cells whilst M2 macrophages are recruited later to promote healing by releasing pro-angiogenic and fibrotic mediators [23].

ROS is produced from normal cellular respiration, exposure to radiation and contact with toxins [24]. The major sources of ROS in cardiac cells include the byproducts of endogenous and exogenous redox systems, such as NADPH oxidase, xanthine oxidase, the mitochondrial electron transport chain, myeloperoxidase (MPO), and uncoupled nitric oxide synthase $[25,26]$. A moderate amount of ROS is required to maintain homeostasis and to mediate physiologic responses via different cellular signaling pathways. Moreover, human body is resistant to mild oxidative stress by employing a defense system which involves enzymes, metal ions and endogenous antioxidant [24]. However, overexpression of NOX and MPO contributes to increased production of ROS. High levels of ROS could react with multiple biomolecules, such as proteins, deoxyribonucleic acid, ribonucleic acid, and lipids, leading to damage of the phospholipid bilayer and the loss of enzyme function, breaking the DNA strands, thereby leading to DNA mutations, lipid peroxidation, and cellular death [24,27]. This can lead to electrophysiological and structural modelling of the atria and therefore to AF [28]. Arachidonic acid is a major component in the phospholipid bilayer. Peroxidation of arachidonic acid yields isoprostanes and their byproducts are readily excreted in urine. Likewise, 8-hydroxy-2'deoxyguanosine $(8-\mathrm{OHdG})$ and urinary biopyrins can also be found in urine when the body has been exposed to oxidative stress [29].

\section{BIOCHEMISTRY OF DIFFERENT URINARY MARKERS}

Biomarkers referred to "biological markers" are defined as the indicators of normal biological processes or pathologic processes that can be precisely measured and evaluated. They can be based on blood, urine, cardiac or cerebral imaging [17, 30 - 37]. Compared with invasive measurements of specific biomarker, noninvasive measurements are more feasible. Moreover, lipids appear to be the most susceptible to the attack of ROS among the biological molecules [38, 39]. Therefore, the levels of lipid peroxidation products may be used as an important biomarker for the measurement of oxidative stress status. The measurement of F2-isoprostanes by methods utilizing mass spectrometry is currently the best available biomarker of lipid peroxidation [38, 40].

Isoprostanes are a group of prostaglandin-like compounds derived from the free radical-catalyzed peroxidation of arachidonic acid [41 - 43]. In addition, 8-iso-PGF2 $\alpha$ is an isoform of F2- isoprostanes and it has recently been identified as a urinary marker of oxidative stress [44] and may be useful for predicting AF.

8-OHdG is an oxidized nucleoside produced as a result of oxidative DNA damage [38]. It is readily excreted in urine and its concentration in urine reflects the extent of DNA damage in the body [45].

Biopyrins are oxidative metabolites of bilirubin produced in response to oxidative stress. They are immediately excreted into urine and can indicate the intensity of oxidation.

\section{PATHOPHYSIOLOGICAL RELATIONSHIP}

\subsection{Oxidative Stress and AF}

ROS are constantly produced as part of normal cellular metabolic processes (such as cellular respiration, antibacterial defense) and external exposures (such ionizing radiation, smoking, and toxins) as discussed earlier [46, 47]. Increased oxidative stress can arise from higher rates of ROS generation compared to its removal rates [15, 17]. As a result of this imbalance, excessive ROS can lead to both structural and electrical remodeling of the atrium [13, 48, 49]. ROS can alter the structure and function of cellular components, such as phospholipids, proteins, and mitochondrial DNA, leading to abnormal cellular signaling [49] (Fig. 1).

Increasing evidence demonstrated that oxidative stress plays an important role in the pathogenesis of AF [50, 51]. A recent study by Sovari et al. [52] indicated that the high levels of ROS were associated with increasing age, heart failure, diabetes mellitus, coronary artery disease and obesity, all of which are risk factors of AF. Several hypotheses have been proposed to explain the association between increased ROS and AF. First, high levels of ROS can augment 
cytokine production from activated inflammatory cells, leading to tissue damage [38, 53]. Secondly, ROS can induce cardiac structural and electrical remodeling. For example, oxidative stress could promote atrial remodeling, by modulating calcium handling proteins or ion channels [24]. These can in turn produce a combination of conduction defects or repolarization abnormalities that can predispose to focal or reentrant activity [54 - 56].

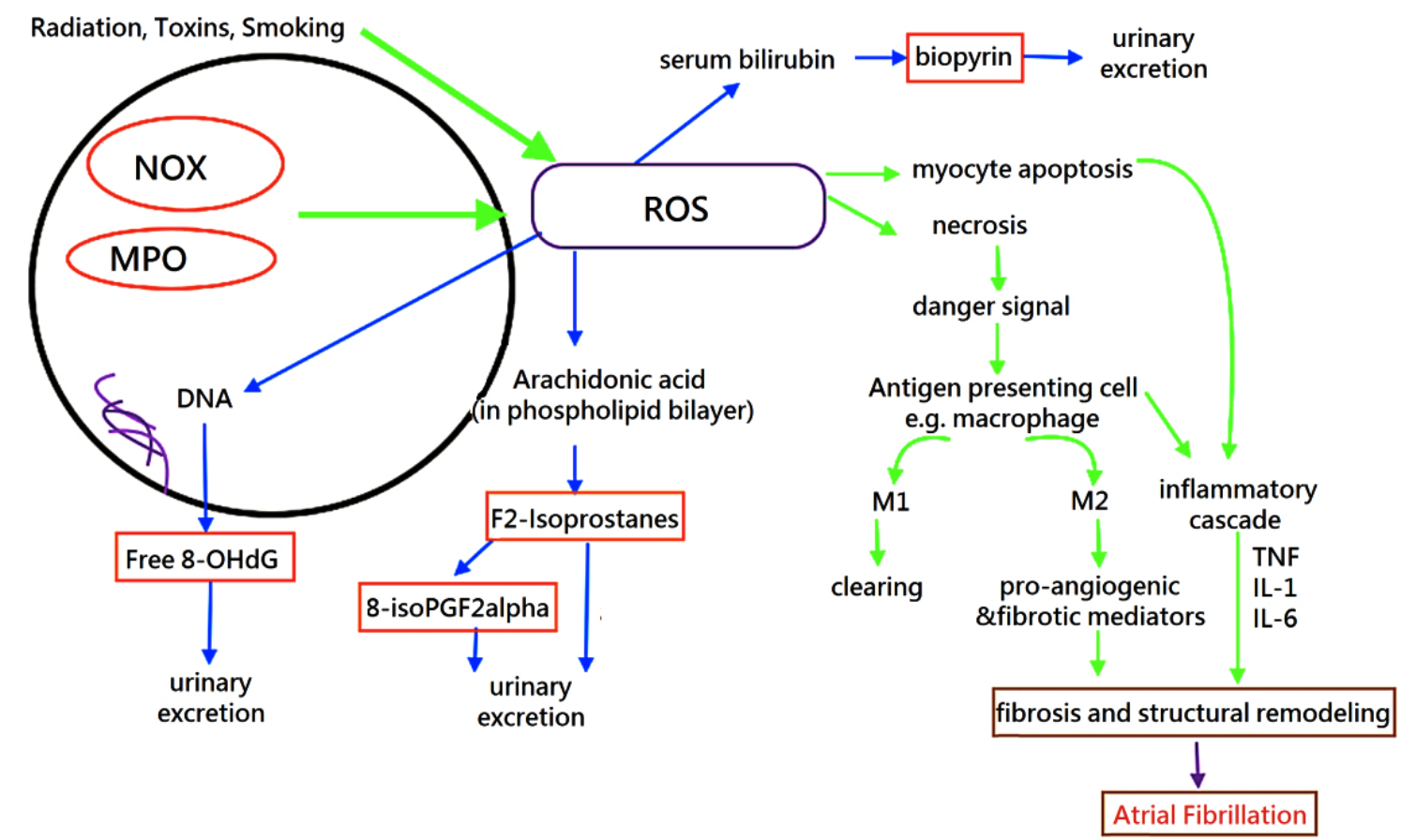

Fig. (1). Physiological response to oxidative stress and the formation of different oxidative biomarkers.

\subsection{Inflammation, Increased Oxidative Stress and AF Pathogenesis}

Experimental evidence suggests that inflammation plays a critical role in the pathogenesis of AF [10, 14 - 16, 57, 58]. The infiltration of inflammatory and immune cells, together with the expression of proteins, mediates the inflammatory response, cardiomyocyte necrosis, interstitial fibrosis and mitochondrial dysfunction, all of which are contributors to AF development and progression [48, 57, 59 - 62]. Previous studies have also identified the reciprocal relationship between angiotensin II (Ang II) and inflammation [49]. Ang II is a regulatory hormone released in response to changes in blood pressure. Experimental studies have demonstrated that Ang II increases the production of proinflammatory cytokines such as IL-6, IL-8, TNF-alpha, adhesion molecules and chemoattractant proteins [53, 63]. At the same time, inflammation increases Ang II production [64] and some inflammatory markers, such as CRP and TNFalpha, increase Ang II receptor expression [65, 66]. This vicious cycle potentiates the development of AF. Indeed, increased levels of inflammatory markers, such as IL and C-Reactive Protein (CRP), are observed in AF patients [67, 68]. Inflammatory mediators mediate electrophysiological and structural remodeling, thereby increasing the vulnerability to $\operatorname{AF}[15,69,70]$.

\section{CLINICAL STUDIES}

A case-control study involving 305 patients with AF and 105 control patients demonstrated a positive relationship between inflammation and the development of AF [57]. More than that, higher concentrations of inflammation biomarkers vary with different stages of AF. IL-10, TNF- $\beta$, and NTpBNP concentrations were significantly higher in persistent or permanent AF compared to paroxysmal AF, whereas no significant differences in the concentrations of IL-8, Monocyte Chemoattractant Protein-1 (MCP-1), and Vascular Endothelial Growth Factor (VEGF) concentrations were observed in those three subtypes of AF after adjustment [57]. The Biomarkers of Oxidative Stress Study (BOSS) demonstrated that isoprostanes were the most sensitive biomarkers of endogenous oxidative stress compared with other biomarkers, such as oxidized lipid, protein, and DNA [39]. Urinary F2-isoprostanes detected by mass spectrometry are the most widely studied and generally accepted as the gold standard to measure lipid peroxidation and oxidative stress in vivo $[44,57,71,72]$. Therefore, oxidative stress seems to have a direct relationship with AF and measuring urinary biomarkers is a potential tool to monitor the development and progression of AF. 


\subsection{Incident AF}

Despite the fact that very few trials have studied the relationship between urinary biomarkers and the occurrence of postoperative AF, an ancillary study of the OPERA trial assessed the incidence of post-operative AF among 551 patients who received cardiac surgeries. This study revealed that urinary levels of $\mathrm{F}_{2}$-isoprostanes and isofuranes at the end of surgery were $20 \%$ and $50 \%$ higher in subjects who developed postoperative AF [51].

\subsection{AF vs Non-AF: Cross-Sectional and Prospective Studies}

Different studies have demonstrated that several biomarkers such as NOXs and MPO predict the risk of AF and morbidity and mortality in AF patients [50, 73]. A recent prospective cohort study found that 8 -iso-PGF2 $\alpha$ levels predict cardiovascular events and total mortality [47]. Several studies have assessed the predictive values of urinary biomarkers of oxidative stress in the context of AF, which are summarized in Table 1 [29, 51, 57, 74 - 76]. The study by Toyama et al. [29] affirmed that urinary $8-\mathrm{OHdG} /$ creatinine levels were significantly increased in AF patients, and reduced when sinus rhythm restored. A prospective study contributed to the evidence in support of the potential pathological role of elevated oxidative stress in the setting of POAF [51]. In another prospective cohort study, $\mathrm{F}_{2}{ }^{-}$ isoprostanes were significantly higher in patients who had recurrence of AF [74]. An additional study showed that urinary isoprostanes and NOX2 activity were significantly higher in patients with paroxysmal/persistent AF than in those with permanent AF and controls [76]. In contrast, an across-sectional study published by Li. et al. [57] showed no significant difference between the concentrations of $\mathrm{F}_{2}$-isoprostanes in the AF and those in the control groups. However, this study design did not take the effects of drugs, such as statins, anti-inflammatory agents, anti-diabetic medications, and angiotensin II blockers into consideration, that can potentially reduce the risk of AF [77]. These novel findings suggest that increased oxidative stress can be detected in the urine for risk stratification when confounding variables are well controlled. Despite most studies show a direct relationship between urinary biomarkers and AF, small sample sizes and the heterogeneity in the biomarkers make it difficult to draw definite conclusions. Therefore, future trials should include a larger group of candidates and unify the biomarkers of interest.

Table1. Summary of the epidemiologic studies regarding urinary oxidative stress biomarkers in patients with AF.

\begin{tabular}{|c|c|c|c|c|c|c|c|c|}
\hline $\begin{array}{l}\text { Author } \\
\text { (Year) }\end{array}$ & $\begin{array}{l}\text { Study } \\
\text { Design }\end{array}$ & $\begin{array}{l}\text { Population } \\
\text { (n) }\end{array}$ & Endpoint & $\begin{array}{c}\text { Biomarkers of } \\
\text { Urine }\end{array}$ & Categories of AF & $\begin{array}{l}\text { Measurement } \\
\text { of Urine }\end{array}$ & $\begin{array}{c}\text { Risk of the Marker of } \\
\text { Urinary Oxidative } \\
\text { Stress in Patients with } \\
\text { AF }\end{array}$ & $\begin{array}{l}\text { Categories } \\
\text { of Results }\end{array}$ \\
\hline $\begin{array}{c}\mathrm{Li} \\
(2010)\end{array}$ & $\mathrm{CS}$ & 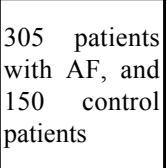 & NA & $\begin{array}{l}\text { Urinary } \mathrm{F}_{2}- \\
\text { isoprostanes }\end{array}$ & $\begin{array}{c}\text { Lone/typical/paro-xysmal/persistent/ } \\
\text { permanent AF }\end{array}$ & $\begin{array}{l}\text { Using gas } \\
\text { chromatography } \\
\text { and mass } \\
\text { spectroscopy. }\end{array}$ & $\begin{array}{c}\text { Concentrations of } \\
\text { Urinary } \mathrm{F}_{2} \text {-isoprostanes } \\
\text { were not increased in } \mathrm{AF} \\
\text { over or in different } \\
\text { subtypes of } \mathrm{AF}(\mathrm{p}=0.50)\end{array}$ & $\begin{array}{c}\text { Not } \\
\text { applicable }\end{array}$ \\
\hline $\begin{array}{c}\text { Cangemi } \\
(2012)\end{array}$ & $\mathrm{CS}$ & $\mid \begin{array}{lr}174 & \text { patients } \\
\text { with } & \mathrm{AF}, \text { and } \\
90 & \text { control } \\
\text { patients }\end{array}$ & NA & $\begin{array}{l}\text { Urinary } \\
\text { isoprostanes }\end{array}$ & $\begin{array}{c}\text { Paroxysmal/ persistent/ permanent } \\
\text { AF }\end{array}$ & $\begin{array}{l}\text { EIA assay } \\
\text { method }\end{array}$ & $\begin{array}{l}\text { Multivariable regression } \\
\text { analyses: urinary } \\
\text { isoprostanes were } \\
\text { independently associated } \\
\text { with the types of } \\
\text { AF(paroxysmal/persistent } \\
\text { VS permanent AF: } \\
\beta=-231, p=0.005 \text { ) }\end{array}$ & Prognostic \\
\hline $\begin{array}{l}\text { Ferro } \\
(2012)\end{array}$ & PS & $\begin{array}{c}144 \text { patients } \\
\text { underwent } \\
\text { electric } \\
\text { cardio-version } \\
\text { of } \\
\text { nonvalvular } \\
\text { persistent } \mathrm{AF}\end{array}$ & \begin{tabular}{|c|}
$\mathrm{AF}$ \\
recurrence
\end{tabular} & $\begin{array}{l}\text { Urinary 8-iso- } \\
\text { PGF } 2 \alpha\end{array}$ & $\begin{array}{l}\text { Non-valvular persistent } \mathrm{AF} \\
\quad \text { (lasting } \geq 7 \text { days). }\end{array}$ & $\begin{array}{l}\text { Using enzyme } \\
\text { immunoassay } \\
\text { method. }\end{array}$ & $\begin{array}{l}\text { In unadjusted analysis, } \\
\text { levels of urinary } \\
\text { isoprostanes were } \\
\text { significantly higher in } \\
\text { patients with AF } \\
\text { recurrence. Urinary } \\
\text { isoprostanes levels were } \\
\text { inversely correlated with } \\
\text { serum vitamin } \mathrm{E} \text { level } \\
(\mathrm{r}=0.626, \mathrm{P}=0.001) .\end{array}$ & $\begin{array}{l}\text { Predictor } \\
\text { of } \\
\text { recurrence }\end{array}$ \\
\hline $\begin{array}{c}\text { Toyama } \\
\text { (2013) }\end{array}$ & - & - & - & - & - & - & - & \\
\hline Study 1 & $\mathrm{CS}$ & $\begin{array}{c}173 \text { patients } \\
\text { with sinus } \\
\text { rhythm and } \\
\text { permanent } \mathrm{AF}\end{array}$ & NA & $\begin{array}{l}\text { Urinary 8- } \\
\text { OHdG }\end{array}$ & Permanent AF & $\begin{array}{l}\text { Enzyme-linked } \\
\text { immunosorbent } \\
\text { assay kit }\end{array}$ & $\begin{array}{c}\text { Urinary } 8-\mathrm{OHdG} / \mathrm{Cr} \text { level } \\
\text { was an independent } \\
\text { factor that significantly } \\
\text { correlated with the } \\
\text { presence of permanent } \\
\text { AF }(\beta=0.36, p<0.001)\end{array}$ & $\begin{array}{l}\text { Predictor } \\
\text { of incident } \\
\text { AF }\end{array}$ \\
\hline
\end{tabular}




\begin{tabular}{|c|c|c|c|c|c|c|c|c|}
\hline $\begin{array}{l}\text { Author } \\
\text { (Year) }\end{array}$ & $\begin{array}{l}\text { Study } \\
\text { Design }\end{array}$ & $\begin{array}{l}\text { Population } \\
\text { (n) }\end{array}$ & Endpoint & $\underset{\text { Urine }}{\text { Biomarkers of }}$ & Categories of AF & $\begin{array}{c}\text { Measurement } \\
\text { of Urine }\end{array}$ & $\begin{array}{c}\text { Risk of the Marker of } \\
\text { Urinary Oxidative } \\
\text { Stress in Patients with } \\
\text { AF }\end{array}$ & $\begin{array}{l}\text { Categories } \\
\text { of Results }\end{array}$ \\
\hline Study 2 & $\mathrm{CS}$ & $\begin{array}{c}36 \text { cardiac } \\
\text { surgery } \\
\text { patients with } \\
\text { persistent AF }\end{array}$ & NA & $\begin{array}{l}\text { Urinary 8- } \\
\text { OHdG and } \\
\text { urinary } \\
\text { biopyrrin }\end{array}$ & Persistent AF & $\begin{array}{l}\text { EIA assay } \\
\text { method }\end{array}$ & \begin{tabular}{|c|} 
8-OHdG/creatinine and \\
biopyrrin/ creatinine \\
levels at the chronic \\
phase were significantly \\
lower than those before \\
cardioversion or catheter \\
ablation $(8.7 \pm 3.2 \mathrm{vs}$. \\
$21.7 \pm 15.1 \mathrm{ng} / \mathrm{mg}, \mathrm{p} .0001$ \\
and $1.7 \pm 1.1 \mathrm{vs} .3 .0 \pm 1.9$ \\
$\mathrm{mU} / \mathrm{mg}, \mathrm{p}<0.0001)$.
\end{tabular} & Prognostic \\
\hline $\begin{array}{l}\text { Pignatelli } \\
(2015)\end{array}$ & PS & $\begin{array}{c}1002 \\
\text { anticoagulated } \\
\text { AF patients }\end{array}$ & $\begin{array}{l}\text { All major } \\
\text { CV events } \\
\text { and death }\end{array}$ & $\begin{array}{l}\text { Urinary 8-iso- } \\
\text { PGF2a }\end{array}$ & Anticoagulated AF & $\begin{array}{l}\text { A validate EIA } \\
\text { assay method }\end{array}$ & $\begin{array}{l}\text { 8-iso-PGF2a levels are } \\
\text { predictive of CV events } \\
\text { and total mortality. F2- } \\
\text { IsoP complements risk } \\
\text { factors in prediction of } \\
\text { CV events. }\end{array}$ & Prognostic \\
\hline $\begin{array}{l}\mathrm{Wu} \\
(2015)\end{array}$ & PS & $\begin{array}{l}551 \text { cardiac } \\
\text { surgery } \\
\text { patients }\end{array}$ & $\begin{array}{l}\text { Incident } \\
\text { POAF }\end{array}$ & $\begin{array}{c}\text { Urinary } \mathrm{F}_{2-} \\
\text { isoprostanes, } \\
\mathrm{F}_{3} \text {-isoprostanes, } \\
\text { and isofurans }\end{array}$ & POAF of $\geq 30$ seconds' duration & $\begin{array}{c}\text { Using gas } \\
\text { chromatography } \\
\text { and mass } \\
\text { spectrometry }\end{array}$ & \begin{tabular}{|c|} 
Multivariate-adjusted OR \\
for urinary Isofurans and \\
F3-isoprostanes were \\
$1.95(95 \% \mathrm{CI} 1.05-3.62$ \\
$\mathrm{p}=0.01)$ and $2.10(95 \% \mathrm{CI}$ \\
$\begin{array}{c}1.04-2.25, \mathrm{p}=0.04) \\
\text { respectively. }\end{array}$
\end{tabular} & $\begin{array}{c}\text { Predictor } \\
\text { of incident } \\
\text { AF }\end{array}$ \\
\hline
\end{tabular}

$\mathrm{AF}=$ Atrial Fibrillation; $\mathrm{CI}=$ Confidence Interval; $\mathrm{CS}=$ Case-control study; $\mathrm{CV}=$ cardiovascular; EIA= Enzyme Immunoassay; NA=Not Available; $\mathrm{OR}=$ Odd Ratio; POAF=Postoperative Atrial Fibrillation; PS= Prospective cohort Study; PUFAs=omega-3 Polyunsaturated Fatty Acids; 8-isoPGF $2 \alpha=$ prostaglandin PGF2alpha.

\subsection{Therapeutic Outcomes}

Many studies support the notion that increased oxidative stress links to the development of AF. Accordingly, reduction in oxidative stress and neutralizing ROS are the keys to reduce the incidence of AF. In an experimental model of AF induced by atrial rapid pacing, enhanced oxidative stress was demonstrated and the vulnerability of AF was reduced by antioxidant treatment [19]. Pre-clinical and clinical studies have also demonstrated an association between biomarkers of oxidative stress and AF [19,20] and that lower levels of antioxidants increased the occurrence or recurrence of $\mathrm{AF}$ in patients undergoing cardiac surgery $[50,74]$. Indeed, the impact of antioxidants has attracted a number of interventional trials on the effect of antioxidants on postoperative AF. A meta-analysis reviewed 15 studies to examine if antioxidants could stop or retard the incidence of AF. Despite these studies have small sample size (ranging from 10 to 104), they consistently showed that antioxidants (vitamin $\mathrm{C}$ and $\mathrm{N}$-acetylcysteine) reduced the incidence of AF after cardiac procedure [78].

\subsection{Prognostic Implications}

The measurement of oxidative stress biomarkers using the products of non-enzymatic reactions between biological molecules and ROS has been an area of intense study [46, 79]. In clinical practice, it is difficult to directly detect ROS in vivo, since they have short lifetimes and reliable methods for quantifying oxidative stress are lacking [80, 81]. On the other hand, urinary biomarkers of oxidative stress are useful indices of redox balance, and have advantages over traditional serum biomarkers because they can be obtained non-invasively and have a low organic/metal content ratio [46]. Moreover, urinary biomarkers can reflect redox balance over a prolonged period, compared to shorter half-lives of Reactive Oxygen Species (ROS) detected in serum biomarkers [46, 79]. Consequently, such urinary biomarkers can be a key indicator for predicting the occurrence or recurrence of AF and cardiovascular events from AF [29, 51, 57, 74 76]. Among the different urinary biomarkers, F2-isoprostanes are useful markers for assessing oxidant injury. Quantifications of F2-isoprostanes in urine varied in different methods. In general, liquid chromatography tandem-mass spectrometry (LC/MS/MS) is a sensitive and specific analytic method by using a solid phase extraction method. A 24hour urine sample $(2 \mathrm{ml})$ of the patients was collected and analyzed, which facilitated us in clinical practice [82].

Studies suggest the cause of AF is inflammation related. Additionally, these findings may potentially have therapeutic implications, as anti-inflammatory therapy has the potential to reduce the occurrence and recurrence of AF $[83,84]$. 


\section{CONCLUSION}

Recent studies support the idea that oxidative stress and inflammation are main contributors to AF. There is accumulating experimental evidence to suggest that urinary biomarkers of oxidative stress, such as $\mathrm{F}_{2}$-IsoPs, can be used for the prediction of AF. F2-isoprostanes and 8-OHdG are currently the recommended biomarkers for monitoring oxidative status, and can be used in large-scale clinical studies.

\section{CONSENT FOR PUBLICATION}

Not applicable.

\section{CONFLICT OF INTEREST}

The authors declare no conflict of interest, financial or otherwise.

\section{ACKNOWLEDGEMENTS}

This work was supported by grants $(30900618,81270245$, and 81570298 to T.L.) from the National Natural Science Foundation of China, and Tianjin Natural Science Foundation

\section{REFERENCES}

[1] Ball J, Carrington MJ, McMurray JJ, Stewart S. Atrial fibrillation: Profile and burden of an evolving epidemic in the 21st century. Int J Cardiol 2013; 167(5): 1807-24. [http://dx.doi.org/10.1016/j.ijcard.2012.12.093]

[2] Lip GY, Nieuwlaat R, Pisters R, Lane DA, Crijns HJ. Refining clinical risk stratification for predicting stroke and thromboembolism in atrial fibrillation using a novel risk factor-based approach: The euro heart survey on atrial fibrillation. Chest 2010; $137(2)$ : $263-72$. [http://dx.doi.org/10.1378/chest.09-1584]

[3] Chugh SS, Havmoeller R, Narayanan K, et al. Worldwide epidemiology of atrial fibrillation: A Global burden of disease 2010 study. Circulation 2014; 129(8): 837-47.

[http://dx.doi.org/10.1161/CIRCULATIONAHA.113.005119]

[4] Guo Y, Tian Y, Wang H, Si Q, Wang Y, Lip GY. Prevalence, incidence, and lifetime risk of atrial fibrillation in China: New insights into the global burden of atrial fibrillation. Chest 2015; 147(1): 109-19. [http://dx.doi.org/10.1378/chest.14-0321]

[5] Freedman B, Potpara TS, Lip GY. Stroke prevention in atrial fibrillation. Lancet 2016; 388(10046): 806-17. [http://dx.doi.org/10.1016/S0140-6736(16)31257-0]

[6] Jørgensen HS, Nakayama H, Reith J, Raaschou HO, Olsen TS. Acute stroke with atrial fibrillation: The Copenhagen stroke study. Stroke 1996; 27(10): 1765-9. [http://dx.doi.org/10.1161/01.STR.27.10.1765]

[7] Kimura K, Minematsu K, Yamaguchi T. Atrial fibrillation as a predictive factor for severe stroke and early death in 15,831 patients with acute ischaemic stroke. J Neurol Neurosurg Psychiatry 2005; 76(5): 679-83. [http://dx.doi.org/10.1136/jnnp.2004.048827]

[8] Bhave PD, Goldman LE, Vittinghoff E, Maselli J, Auerbach A. Incidence, predictors, and outcomes associated with postoperative atrial fibrillation after major noncardiac surgery. Am Heart J 2012; 164(6): 918-24. [http://dx.doi.org/10.1016/j.ahj.2012.09.004]

[9] Bessissow A, Khan J, Devereaux PJ, Alvarez-Garcia J, Alonso-Coello P. Postoperative atrial fibrillation in non-cardiac and cardiac surgery: An overview. J Thromb Haemost 2015; 13(11): 2134. [http://dx.doi.org/10.1111/jth.12974]

[10] Gorenek B, Pelliccia A, Benjamin EJ, et al. European Heart Rhythm Association (EHRA)/European Association of Cardiovascular Prevention and Rehabilitation (EACPR) position paper on how to prevent atrial fibrillation endorsed by the Heart Rhythm Society (HRS) and Asia Pacific Heart Rhythm Society (APHRS). Europace 2017; 19(2): 190-225. [http://dx.doi.org/10.1093/europace/euw242]

[11] Tse G, Lai ET, Tse V, Yeo JM. Molecular and electrophysiological mechanisms underlying cardiac arrhythmogenesis in diabetes mellitus. J Diabetes Res 2016; 2016: 2848759.

[http://dx.doi.org/10.1155/2016/2848759]

[12] Korantzopoulos P, Kolettis TM, Galaris D, Goudevenos JA. The role of oxidative stress in the pathogenesis and perpetuation of atrial fibrillation. Int J Cardiol 2007; 115(2): 135-43. [http://dx.doi.org/10.1016/j.ijcard.2006.04.026]

[13] Liu T, Li L, Korantzopoulos P, Goudevenos JA, Li G. Meta-analysis of association between C-reactive protein and immediate success of electrical cardioversion in persistent atrial fibrillation. Am J Cardiol 2008; 101(12): 1749-52. 
[http://dx.doi.org/10.1016/j.amjcard.2008.02.066]

[14] Liu T, Shao Q, Korantzopoulos P, Liu E, Xu G, Li G. Serum levels of nicotinamide-adenine dinucleotide phosphate oxidase 4 are associated with non-valvular atrial fibrillation. Biomed Rep 2015; 3(6): 864-8. [http://dx.doi.org/10.3892/br.2015.504]

[15] Hu YF, Chen YJ, Lin YJ, Chen SA. Inflammation and the pathogenesis of atrial fibrillation. Nat Rev Cardiol 2015; 12(4): $230-43$. [http://dx.doi.org/10.1038/nrcardio.2015.2]

[16] Vlachos K, Letsas KP, Korantzopoulos P, et al. Prediction of atrial fibrillation development and progression: Current perspectives. World J Cardiol 2016; 8(3): 267-76.

[http://dx.doi.org/10.4330/wjc.v8.i3.267]

[17] Griffiths HR, Lip GY. New biomarkers and risk stratification in atrial fibrillation: Simplicity and practicality matter. Circulation 2014; 130(21): 1837-9. [http://dx.doi.org/10.1161/CIRCULATIONAHA.114.012870]

[18] Zakkar M, Ascione R, James AF, Angelini GD, Suleiman MS. Inflammation, oxidative stress and postoperative atrial fibrillation in cardiac surgery. Pharmacol Ther 2015; 154: 13-20. [http://dx.doi.org/10.1016/j.pharmthera.2015.06.009]

[19] Carnes CA, Chung MK, Nakayama T, et al. Ascorbate attenuates atrial pacing-induced peroxynitrite formation and electrical remodeling and decreases the incidence of postoperative atrial fibrillation. Circ Res 2001; 89(6): E32-8. [http://dx.doi.org/10.1161/hh1801.097644]

[20] Okada A, Kashima Y, Tomita T, et al. Characterization of cardiac oxidative stress levels in patients with atrial fibrillation. Heart Vessels 2016; 31(1): 80-7. [http://dx.doi.org/10.1007/s00380-014-0582-8]

[21] Rock KL, Kono H. The inflammatory response to cell death. Annu Rev Pathol 2008; 3: 99-126. [http://dx.doi.org/10.1146/annurev.pathmechdis.3.121806.151456]

[22] He G, Tan W, Wang B, et al. Increased M1 macrophages infiltration Is associated with thrombogenesis in rheumatic mitral stenosis patients with atrial fibrillation. PLoS One 2016; 11(3): e0149910. [http://dx.doi.org/10.1371/journal.pone.0149910]

[23] Chinetti-Gbaguidi G, Colin S, Staels B. Macrophage subsets in atherosclerosis. Nat Rev Cardiol 2015; 12(1): 10-7. [http://dx.doi.org/10.1038/nrcardio.2014.173]

[24] Van Wagoner DR. Oxidative stress and inflammation in atrial fibrillation: Role in pathogenesis and potential as a therapeutic target. J Cardiovasc Pharmacol 2008; 52(4): 306-13. [http://dx.doi.org/10.1097/FJC.0b013e31817f9398]

[25] Friedrichs K, Baldus S, Klinke A. Fibrosis in atrial fibrillation - role of reactive species and MPO. Front Physiol 2012; 3: 214. [http://dx.doi.org/10.3389/fphys.2012.00214]

[26] Murdoch CE, Zhang M, Cave AC, Shah AM. NADPH oxidase-dependent redox signalling in cardiac hypertrophy, remodelling and failure. Cardiovasc Res 2006; 71(2): 208-15.

[http://dx.doi.org/10.1016/j.cardiores.2006.03.016]

[27] Dudley SC, Hoch NE, McCann LA, et al. Atrial fibrillation increases production of superoxide by the left atrium and left atrial appendage: Role of the NADPH and xanthine oxidases. Circulation 2005; 112(9): 1266-73. [http://dx.doi.org/10.1161/CIRCULATIONAHA.105.538108]

[28] Tse G, Yan BP, Chan YW, Tian XY, Huang Y. Reactive oxygen species, endoplasmic reticulum stress and mitochondrial dysfunction: The link with cardiac arrhythmogenesis. Front Physiol 2016; 7: 313. [http://dx.doi.org/10.3389/fphys.2016.00313]

[29] Toyama K, Yamabe H, Uemura T, et al. Analysis of oxidative stress expressed by urinary level of 8-hydroxy-2'-deoxyguanosine and biopyrrin in atrial fibrillation: effect of sinus rhythm restoration. Int J Cardiol 2013; 168(1): 80-5. [http://dx.doi.org/10.1016/j.ijcard.2012.09.068]

[30] Lip GY. Stroke and bleeding risk assessment in atrial fibrillation: When, how, and why? Eur Heart J 2013; 34(14): 1041-9. [http://dx.doi.org/10.1093/eurheartj/ehs435]

[31] Cheung A, Gong M, Bellanti R, et al. Cancer antigen-125 and risk of atrial fibrillation: A systematic review and meta-analysis. Heart Asia 2018; 10(1): e010970. [http://dx.doi.org/10.1136/heartasia-2017-010970]

[32] Weymann A, Popov AF, Sabashnikov A, et al. Baseline and postoperative levels of C-reactive protein and interleukins as inflammatory predictors of atrial fibrillation following cardiac surgery: A systematic review and meta-analysis. Kardiol Pol 2018; 76(2): 440-51. [http://dx.doi.org/10.5603/KP.a2017.0242]

[33] Shao Q, Korantzopoulos P, Letsas KP, et al. Red blood cell distribution width as a predictor of atrial fibrillation. J Clin Lab Anal 2018; 32(5): e22378..

[http://dx.doi.org/10.1002/jcla.22378] 
[34] Weymann A, Ali-Hasan-Al-Saegh S, Popov AF, et al. Haematological indices as predictors of atrial fibrillation following isolated coronary artery bypass grafting, valvular surgery, or combined procedures: A systematic review with meta-analysis. Kardiol Pol 2018; 76(1): 107-18. [http://dx.doi.org/10.5603/KP.a2017.0179]

[35] Zhang N, Tse G, Liang X, Li G, Liu T. Telomere length: A newly marker for predicting atrial fibrillation? Int J Cardiol 2017 ; 239 : 21. [http://dx.doi.org/10.1016/j.ijcard.2017.02.125]

[36] Qi W, Zhang N, Korantzopoulos P, et al. Serum glycated hemoglobin level as a predictor of atrial fibrillation: A systematic review with metaanalysis and meta-regression. PLoS One 2017; 12(3): e0170955. [http://dx.doi.org/10.1371/journal.pone.0170955]

[37] Weymann A, Ali-Hasan-Al-Saegh S, Sabashnikov A, et al. Prediction of new-onset and recurrent atrial fibrillation by complete blood count tests: A comprehensive systematic review with meta-analysis. Med Sci Monit Basic Res 2017; 23: 179-222. [http://dx.doi.org/10.12659/MSMBR.903320]

[38] Fraga CG, Shigenaga MK, Park JW, Degan P, Ames BN. Oxidative damage to DNA during aging: 8-hydroxy-2'-deoxyguanosine in rat organ DNA and urine. Proc Natl Acad Sci USA 1990; 87(12): 4533-7. [http://dx.doi.org/10.1073/pnas.87.12.4533]

[39] Kadiiska MB, Gladen BC, Baird DD, et al. Biomarkers of oxidative stress study II: Are oxidation products of lipids, proteins, and DNA markers of CCl4 poisoning? Free Radic Biol Med 2005; 38(6): 698-710. [http://dx.doi.org/10.1016/j.freeradbiomed.2004.09.017]

[40] Roberts LJ II, Milne GL. Isoprostanes. J Lipid Res 2009; 50(Suppl.): S219-23. [http://dx.doi.org/10.1194/jlr.R800037-JLR200]

[41] Renke M, Knap N, Tylicki L, et al. Isoprostanes - important marker of the oxidative stress estimation in patients with chronic kidney disease. Pol Merkuriusz Lek 2013; 34(199): 14-7.

[42] Il'yasova D, Wagenknecht LE, Spasojevic I, et al. Urinary F2-isoprostanes and metabolic markers of fat oxidation. Oxid Med Cell Longev 2015; 2015: 729191. [http://dx.doi.org/10.1155/2015/729191]

[43] Basu S, Nozari A, Liu XL, Rubertsson S, Wiklund L. Development of a novel biomarker of free radical damage in reperfusion injury after cardiac arrest. FEBS Lett 2000; 470(1): 1-6. [http://dx.doi.org/10.1016/S0014-5793(00)01279-5]

[44] Halliwell B, Lee CY. Using isoprostanes as biomarkers of oxidative stress: Some rarely considered issues. Antioxid Redox Signal 2010; 13(2): 145-56. [http://dx.doi.org/10.1089/ars.2009.2934]

[45] Yamamoto M, Maeda H, Hirose N, et al. Bilirubin oxidation provoked by nitric oxide radicals predicts the progression of acute cardiac allograft rejection. Am J Transplant 2007; 7(8): 1897-906. [http://dx.doi.org/10.1111/j.1600-6143.2007.01868.x]

[46] Il'yasova D, Scarbrough P, Spasojevic I. Urinary biomarkers of oxidative status. Clin Chim Acta 2012; 413(19-20): 1446-53. [http://dx.doi.org/10.1016/j.cca.2012.06.012]

[47] Chatgilialoglu C, Ferreri C, Masi A, et al. Free radicals in chemical biology: From chemical behavior to biomarker development. J Vis Exp 2013; 74

[http://dx.doi.org/10.3791/50379]

[48] Frustaci A, Chimenti C, Bellocci F, Morgante E, Russo MA, Maseri A. Histological substrate of atrial biopsies in patients with lone atrial fibrillation. Circulation 1997; 96(4): 1180-4. [http://dx.doi.org/10.1161/01.CIR.96.4.1180]

[49] Boos CJ, Anderson RA, Lip GY. Is atrial fibrillation an inflammatory disorder? Eur Heart J 2006; 27(2): 136-49. [http://dx.doi.org/10.1093/eurheartj/ehi645]

[50] Youn JY, Zhang J, Zhang Y, Chen H, Liu D, Ping P. Oxidative stress in atrial fibrillation: An emerging role of NADPH oxidase. J Mol Cell Cardiol 2013; 62: 72-9. [http://dx.doi.org/10.1016/j.yjmcc.2013.04.019]

[51] $\mathrm{Wu} \mathrm{JH}$, Marchioli R, Silletta MG, et al. Oxidative stress biomarkers and incidence of postoperative atrial fibrillation in the omega-3 fatty acids for prevention of postoperative atrial fibrillation (OPERA) Trial. J Am Heart Assoc 2015; 4(5): e001886 [http://dx.doi.org/10.1161/JAHA.115.001886]

[52] Sovari AA, Dudley SC Jr. Reactive oxygen species-targeted therapeutic interventions for atrial fibrillation. Front Physiol 2012 ; 3: 311. [http://dx.doi.org/10.3389/fphys.2012.00311]

[53] Costanzo A, Moretti F, Burgio VL, et al. Endothelial activation by angiotensin II through NFkappaB and p38 pathways: Involvement of NFkappaB-inducible kinase (NIK), free oxygen radicals, and selective inhibition by aspirin. J Cell Physiol 2003; $195(3)$ : $402-10$. [http://dx.doi.org/10.1002/jcp.10191]

[54] Choy L, Yeo JM, Tse V, Chan SP. Tse. Cardiac disease and arrhythmogenesis: Mechanistic insights from mouse models. Int J Cardiol Heart Vasc 2016; 12: 1-10. [http://dx.doi.org/10.1016/j.ijcha.2016.05.005] 
[55] Tse G, Lai ET, Yeo JM, Tse V, Wong SH. Mechanisms of electrical activation and conduction in the gastrointestinal system: Lessons from cardiac electrophysiology. Front Physiol 2016; 7: 182. [http://dx.doi.org/10.3389/fphys.2016.00182]

[56] Tse G, Yeo JM. Conduction abnormalities and ventricular arrhythmogenesis: The roles of sodium channels and gap junctions. Int J Cardiol Heart Vasc 2015; 9: 75-82. [http://dx.doi.org/10.1016/j.ijcha.2015.10.003]

[57] Li J, Solus J, Chen Q, et al. Role of inflammation and oxidative stress in atrial fibrillation. Heart Rhythm 2010; 7(4): 438-44. [http://dx.doi.org/10.1016/j.hrthm.2009.12.009]

[58] Karam BS, Chavez-Moreno A, Koh W, Akar JG, Akar FG. Oxidative stress and inflammation as central mediators of atrial fibrillation in obesity and diabetes. Cardiovasc Diabetol 2017; 16(1): 120. [http://dx.doi.org/10.1186/s12933-017-0604-9]

[59] Guo Y, Lip GY, Apostolakis S. Inflammation in atrial fibrillation. J Am Coll Cardiol 2012; 60(22): $2263-70$. [http://dx.doi.org/10.1016/j.jacc.2012.04.063]

[60] Liu C, Liu R, Fu H, et al. Pioglitazone attenuates atrial remodeling and vulnerability to atrial fibrillation in alloxan-induced diabetic rabbits. Cardiovasc Ther 2017; 35(5): e12284.

[http://dx.doi.org/10.1111/1755-5922.12284]

[61] Zhang X, Zhang Z, Zhao Y, et al. Alogliptin, a dipeptidyl peptidase-4 inhibitor, alleviates atrial remodeling and improves mitochondrial function and biogenesis in diabetic rabbits. J Am Heart Assoc 2017; 6(5): e005945. [http://dx.doi.org/10.1161/JAHA.117.005945]

[62] Fu H, Li G, Liu C, et al. Probucol prevents atrial ion channel remodeling in an alloxan-induced diabetes rabbit model. Oncotarget 2016; 7(51): 83850-8.

[http://dx.doi.org/10.18632/oncotarget.13339]

[63] Tamarat R, Silvestre JS, Durie M, Levy BI. Angiotensin II angiogenic effect in vivo involves vascular endothelial growth factor-and inflammation-related pathways. Lab Invest 2002; 82(6): 747-56. [http://dx.doi.org/10.1097/01.LAB.0000017372.76297.EB]

[64] Maksimowicz-McKinnon K, Bhatt DL, Calabrese LH. Recent advances in vascular inflammation: C-reactive protein and other inflammatory biomarkers. Curr Opin Rheumatol 2004; 16(1): 18-24. [http://dx.doi.org/10.1097/00002281-200401000-00005]

[65] Kranzhöfer R, Schmidt J, Pfeiffer CA, Hagl S, Libby P, Kübler W. Angiotensin induces inflammatory activation of human vascular smooth muscle cells. Arterioscler Thromb Vasc Biol 1999; 19(7): 1623-9. [http://dx.doi.org/10.1161/01.ATV.19.7.1623]

[66] Peng J, Gurantz D, Tran V, Cowling RT, Greenberg BH. Tumor necrosis factor-alpha-induced AT1 receptor upregulation enhances angiotensin II-mediated cardiac fibroblast responses that favor fibrosis. Circ Res 2002; 91(12): 1119-26. [http://dx.doi.org/10.1161/01.RES.0000047090.08299.D5]

[67] Liu T, Li G, Li L, Korantzopoulos P. Association between C-reactive protein and recurrence of atrial fibrillation after successful electrical cardioversion: a meta-analysis. J Am Coll Cardiol 2007; 49(15): 1642-8. [http://dx.doi.org/10.1016/j.jacc.2006.12.042]

[68] Chung MK, Martin DO, Sprecher D, et al. C-reactive protein elevation in patients with atrial arrhythmias: Inflammatory mechanisms and persistence of atrial fibrillation. Circulation 2001; 104(24): 2886-91. [http://dx.doi.org/10.1161/hc4901.101760]

[69] Kaireviciute D, Blann AD, Balakrishnan B, et al. Update on the association of inflammation and atrial fibrillation. J Cardiovasc Electrophysiol 2010; 21(9): 1064-70. [http://dx.doi.org/10.1111/j.1540-8167.2010.01774.x]

[70] Kaireviciute D, Blann AD, Balakrishnan B, et al. Characterisation and validity of inflammatory biomarkers in the prediction of post-operative atrial fibrillation in coronary artery disease patients. Thromb Haemost 2010; 104(1): 122-7. [http://dx.doi.org/10.1160/TH09-12-0837]

[71] Ky B, Burke A, Tsimikas S, et al. The influence of pravastatin and atorvastatin on markers of oxidative stress in hypercholesterolemic humans. J Am Coll Cardiol 2008; 51(17): 1653-62. [http://dx.doi.org/10.1016/j.jacc.2008.01.026]

[72] Jahn U, Galano JM, Durand T. Beyond prostaglandins--chemistry and biology of cyclic oxygenated metabolites formed by free-radical pathways from polyunsaturated fatty acids. Angew Chem Int Ed Engl 2008; 47(32): 5894-955. [http://dx.doi.org/10.1002/anie.200705122]

[73] Zhang Z, Li G, Liu T. Psoriasis and risk of atrial fibrillation. Int J Cardiol 2015; 185: 301-3. [http://dx.doi.org/10.1016/j.ijcard.2015.03.149]

[74] Ferro D, Franciosa P, Cangemi R, et al. Serum levels of vitamin E are associated with early recurrence of atrial fibrillation after electric cardioversion. Circ Arrhythm Electrophysiol 2012; 5(2): 327-33. [http://dx.doi.org/10.1161/CIRCEP.111.968248] 
[75] Pignatelli P, Pastori D, Carnevale R, et al. Serum NOX2 and urinary isoprostanes predict vascular events in patients with atrial fibrillation. Thromb Haemost 2015; 113(3): 617-24. [http://dx.doi.org/10.1160/TH14-07-0571]

[76] Cangemi R, Celestini A, Calvieri C, et al. Different behaviour of NOX2 activation in patients with paroxysmal/persistent or permanent atrial fibrillation. Heart 2012; 98(14): 1063-6. [http://dx.doi.org/10.1136/heartjnl-2012-301952]

[77] Zhang Z, Zhang X, Korantzopoulos P, et al. Thiazolidinedione use and atrial fibrillation in diabetic patients: A meta-analysis. BMC Cardiovasc Disord 2017; 17(1): 96. [http://dx.doi.org/10.1186/s12872-017-0531-4]

[78] Violi F, Pastori D, Pignatelli P, Loffredo L. Antioxidants for prevention of atrial fibrillation: A potentially useful future therapeutic approach? A review of the literature and meta-analysis. Europace 2014; 16(8): 1107-16. [http://dx.doi.org/10.1093/europace/euu040]

[79] Halliwell B, Whiteman M. Measuring reactive species and oxidative damage in vivo and in cell culture: how should you do it and what do the results mean? Br J Pharmacol 2004; 142(2): 231-55. [http://dx.doi.org/10.1038/sj.bjp.0705776]

[80] Pryor WA. Oxy-radicals and related species: Their formation, lifetimes, and reactions. Annu Rev Physiol 1986; $48: 657-67$. [http://dx.doi.org/10.1146/annurev.ph.48.030186.003301]

[81] Morrow JD. Quantification of isoprostanes as indices of oxidant stress and the risk of atherosclerosis in humans. Arterioscler Thromb Vasc Biol 2005; 25(2): 279-86.

[http://dx.doi.org/10.1161/01.ATV.0000152605.64964.c0]

[82] Prasain JK, Arabshahi A, Taub PR, et al. Simultaneous quantification of F2-isoprostanes and prostaglandins in human urine by liquid chromatography tandem-mass spectrometry. J Chromatogr B Analyt Technol Biomed Life Sci 2013; 913-914: 161-8. [http://dx.doi.org/10.1016/j.jchromb.2012.12.009]

[83] De Caterina R, Ruigomez A, Rodriguez LA. Long-term use of anti-inflammatory drugs and risk of atrial fibrillation. Arch Intern Med 2010; 170(16): 1450-5. [http://dx.doi.org/10.1001/archinternmed.2010.305]

[84] Liu G, Yan YP, Zheng XX, et al. Meta-analysis of nonsteroidal anti-inflammatory drug use and risk of atrial fibrillation. Am J Cardiol 2014; 114(10): 1523-9.

[http://dx.doi.org/10.1016/j.amjcard.2014.08.015]

\section{(C) 2018 Meng et al.}

This is an open access article distributed under the terms of the Creative Commons Attribution 4.0 International Public License (CC-BY 4.0), a copy of which is available at: (https://creativecommons.org/licenses/by/4.0/legalcode). This license permits unrestricted use, distribution, and reproduction in any medium, provided the original author and source are credited. 